\title{
Faktor-Faktor Fundamental, Kondisi Makro Ekonomi dan Return Saham Perusahaan Pertambangan di Bursa Efek Indonesia
}

\author{
Sailendra ${ }^{1}$, Suratno ${ }^{2}$ \\ ${ }^{1}$ Universitas Pancasila, Jl. Srengseng Sawah, Jagakarsa, Jakarta Selatan 12640 \\ ${ }^{2}$ Universitas Esa Unggul, Jalan Arjuna Utara No.9, Kebon Jeruk - Jakarta Barat 11510
}

I N F O A R T I K E L

\section{JEL Classification:}

G14

F62

\section{Keywords:}

debt to equity ratio, return on equity, total asset turnover, price to book value, inflation, stocks return

\section{$\begin{array}{llllllll}A & B & S & T & R & A & C & T\end{array}$}

The main goal is to get investors to invest a high return. The mining company is an industry sector that gives investors hope to get high returns because the sector is undergoing a lot of changes in regulation since 2008. The government has tried to protect the export of raw materials mining and requires employers to process before being exported. Macroeconomic conditions and fundamental factor is that many factors affect stock prices. This study aimed to prove the effect of fundamental factors and macroeconomic conditions toward stock returns on mining companies. The results showed that there are significant fundamental factors and macroeconomic conditions toward stock returns. Fundamental factors that affect the return is the ratio of price to book value, while the macroeconomic conditions which proved to affect the return is inflation

\section{A B S T R A K}

Tujuan utama investor berinvestasi adalah mendapatkan return yang tinggi. Perusahaan tambang merupakan sektor industri yang memberikan harapan investor untuk mendapatkan return tinggi karena sektor ini mengalami banyak perubahan regulasi sejak tahun 2008. Pemerintah berupaya memproteksi ekspor bahan mentah tambang dan mewajibkan pengusaha untuk mengolahnya sebelum diekspor. Kondisi ekonomi makro dan faktor fundamental merupakan faktor yang banyak mempengaruhi harga saham. Penelitian ini bertujuan untuk membuktikan pengaruh faktor fundamental dan kondisi ekonomi makro terhadap return saham pada perusahaan tambang. Hasil penelitian adalah terdapat pengaruh faktor fundamental dan kondisi ekonomi makro terhadap return saham. Faktor fundamental yang ditemukan berpengaruh adalah rasio price to book value, sedangkan kondisi ekonomi makro yang terbukti berpengaruh adalah inflasi.

\section{Pendahuluan}

Pasar modal mempunyai posisi yang strategis dan penting bagi investor, dunia investasi dan suatu negara pada era digitalisasi ekonomi pada saat ini, karena pasar modal tidak lagi hanya sekedar tempat bertemunya para investor yang ingin berinvestasi di pasar modal dan korporasi yang ingin mencari dana lewat pasar modal, akan tetapi telah menjadi salah satu indikator yang dapat memberikan isyarat dan menggambarkan akan keadaan perekonomian yang terjadi pada suatu negara yang dapat dijadikan petunjuk dan bahan pertimbangan untuk melakukan keputusan investasi. Pergerakan serta fenomena indikator ekonomi yang berasal dari faktor fundamental keuangan serta variabel makro eknomi sebagai faktor yang kecenderunganya menyebabkan terjadinya kenaikan dan penurunan nilai indeks

*Email Korespondensi: ${ }^{1}$ sailendra.nangadam@yahoo.com, ${ }^{2}$ soeratno_54@yahoo.com 
harga saham selalu berpengaruh terhadap return saham, merupakan refleksi atas aktifitas perdagangan saham dipasar modal yang patut dicermati oleh investor.

Saham yang dijual di bursa efek oleh perusahaan-perusahaan yang telah terbuka (go-public), salah satu komoditas investasi yang tergolong beresiko tinggi, karena sifat komoditasnya yang sangat rentan terhadap pengaruh perubahan yang ada dilingkunganya, baik itu faktor fundamental keuangan yang berasal dari dalam, serta pengaruh ekonomi, politik dan yang berasal dari luar perusahaan baik yang berasal dari dalam negeri ataupun luar negeri yang dapat memberikan dampak serta pengaruh positif ataupun negatif, secara langsung ataupun tidak langsung, yang akan mempengaruhi harga dan tingkat return saham return saham yang diterbitkan. Menurut Ang (1997) jika kondisi atau indikator makro ekonomi mendatang diperkirakan jelek, maka kemungkinan besar refleksi indeks harga saham menurun, demikian pula sebaliknya. Pergerakan serta fenomena indikator ekonomi yang berasal dari faktor fundamental keuangan serta variabel makro sebagai faktor yang kecenderunganya menyebabkan terjadinya kenaikan dan penurunan nilai indeks harga saham selalu berpengaruh terhadap tingkat return saham, merupakan refleksi atas aktifitas perdagangan saham di pasar modal, menjadikanya menarik untuk dianalisis. Data perubahan return saham rata-rata pada perusahaan pertambangan yang terdaftar di BEI pada periode 2007 - 2011, dapat dilihat pada Gambar 1. sebagai berikut:

\section{Gambar 1}

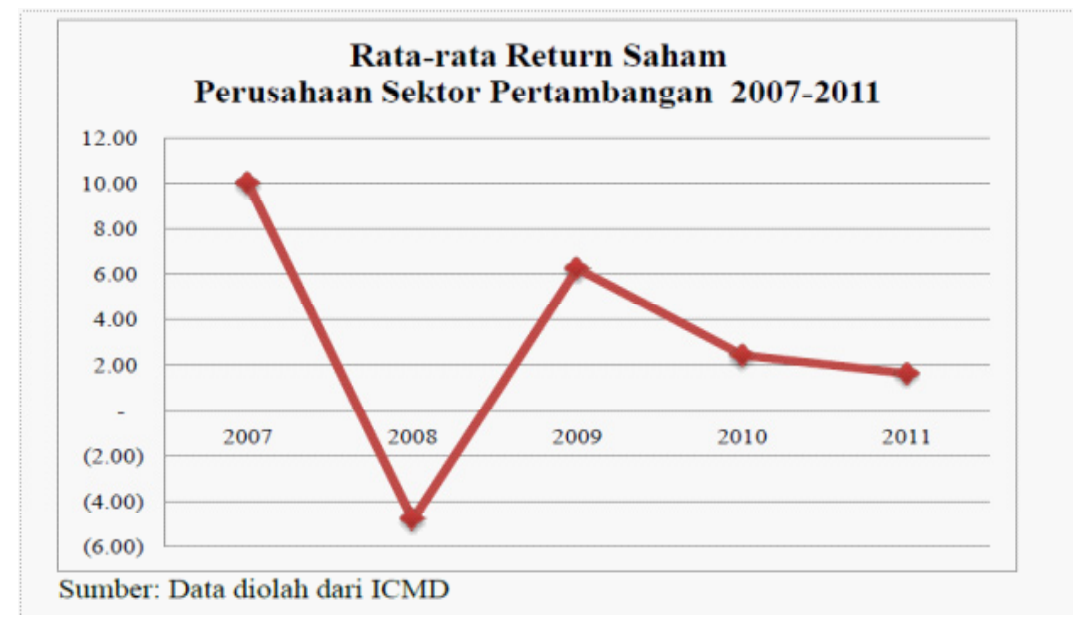

yang diperjual belikan di pasar modal.

Asimetri informasi dan adanya persepsi informasi yang tidak sama antara investor satu dengan yang lainnya sesuai dengan data dan informasi yang mereka miliki serta kepentingan yang berbeda untuk keuntungan masingmasing pihak merupakan faktor utama yang dapat menyebabkan harga saham berubah dari waktu ke waktu. Dalam melakukan pemilihan investasi, informasi di pasar modal akan selalu dipengaruhi oleh informasi fundamental dan informasi teknikal (Chung, 1997). Informasi fundamental ialah informasi yang berhubungan dengan kinerja serta kondisi internal perusahaan yang terdiri dari variabel-variabel fundamental keuangan yang mestinya bisa dikontrol, analisis ini bermula dari siklus perusahaan secara umum, selanjutnya ke sektor industrinya, dan kemudian evaluasi terhadap harga dan
Penelitian atas pengaruh variabel fundamental keuangan dan makro ekonomi yang dihubungkan dengan return saham telah banyak dilakukan oleh peneliti terdahulu, diantaranya oleh Pahlevi (2012), Tarazi dan Gallato (2012), Raharjo (2011), Geetha, Caroline, Mohidin, Chandran dan Victoria (2011), Markoni (2009), Fidiana (2009), Martani, Mulyono dan Khairurizka (2009), Aisyah (2009), Ganto, Khadafi, Albra dan Syamni (2008), Widjaja (2009), Sulaiman dan Anahadi (2008), Poernamawatie (2008), Harahap dan Pasaribu (2007), Sari dan Soytas (2005) serta Nuringsih (2005). Meskipun penelitian dan studi tentang return saham telah banyak dilakukan oleh peneliti terdahulu, namun penelitian dibidang ini masih sangat menarik untuk diteliti karena hasil temuan antara peneliti yang satu dengan yang lainya tidak selalu konsisten serta variable- 
variabel - variabel yang mempengaruhi selalu berubah sesuai dengan kondisi dan kemajuan teknologi, terutama yang disebabkan dan dipengaruhi oleh faktor makro ekonomi dunia yang semakin dinamis dan sensitif terhadap pasar saham.

Penelitian ini menggunakan variabel rasio keuangan sebagaimana yang dikemukakan oleh Harmono (2009), yaitu, rasio solvabilitas yang diukur dengan Debt to Asset Ratio (DAR), rasio profitabilitas yang diukur dengan Return On Equity (ROE), rasio aktifitas yang diukur dengan Total Asset Turn Over (TATO), serta rasio pasar yang diukur dengan Price Book Value (PBV) serta faktor makro ekonomi yang selalu berubah dari waktu ke waktu merupakan salah satu faktor yang dapat mempengaruhi pergerakan harga saham yang diperdagangkan di pasar modal secara sensitif salah satunya adalah Inflasi sebagai variabel independen serta return saham pada perusahaan sektor pertambangan yang terdaftar di Bursa Efek Indonesia sebagai variabel dependennya. Variabel - variabel independen tersebut dipilih kasrena dari berbagai penelitian yang telah dilakukan oleh peneliti terdahulu, terdapat hasil penelitian yang tidak konsisten antara satu peneliti dengan peneliti lainnya atas hasil penelitian yang telah mereka lakukan, peneliti ingin membuktikan secara empiris apakah varibel-varibel yang ada tersebut masih relevan dan seberapa besar pengaruhnya terhadap return saham pada era digitalisasi ekonomi saat ini, khususnya untuk industri sektor pertambangan.

\section{Telaah Teori dan Pengembangan Hipotesis}

\subsection{Teori sinyal dan Teori Pasar Efisien}

Perusahaan sektor pertambangan pada umumnya adalah usaha yang memerlukan kapital yang besar untuk membiayai operasional perusahaan dengan resiko yang sangat tinggi akan ketidak pastian cadangan dan return investasi yang dihasilkan yang mengutamakan pertumbuhan jangka panjang dengan nilai perusahaan yang tinggi. Teori Sinyal (Signaling Theory) pihak manajemen perusahaan dianggap mempunyai informasi yang cukup atas perusahaan tersebut, informasi yang disampaikan oleh manajemen kepada pihak luar melalui laporan keuangan akan ditangkap oleh pihak investor sebagai sinyal terhadap prospek dan resiko perusahaan dimasa yang akan datang, baik itu bersifat positif maupun negatif yang akan berpengaruh terhadap kenaikan sertapenurunan ekuitas perusahaan. Salah satu cara untuk mengurangi distorsi informasi tersebut adalah dengan memberikan sinyal kepada pihak luar melalui informasi keuangan yang terpercaya dan disampaikan tepat waktu, hal ini dapat dipercaya akan mengurangi ketidakpastian mengenai prospek dan resiko perusahaan dimasa yang akan datang (Wolk et al, 2000).

Teori Pasar Efisien (Efficient Market Theory) mengasumsikan bahwa rata-rata informasi yang dimiliki oleh pelaku pasar adalah benar, sehingga semua pelaku pasar dapat menyerap dan mengelola informasi tersebut secara rasional. Efisiensi dalam pasar saham menunjukan secara tidak langsung bahwa seluruh informasi relevan yang tersedia tentang suatu saham langsung tercermin dalam harganya (Weston \& Copeland, 1992).

Teori Sinyal dan Efisiensi pasar merupakan petunjuk bahwa volatilitas harga saham yang berpengaruh terhadap return saham berasal dari tarik menarik kepentingan antara dua kelompok atas informasi yang disampaikan oleh manajemen kepada investor yang menciptakan asimetri informasi dipasar ekuitas sesuai dengan porsi dan pemahaman yang diterima oleh masing-masing investor, sehingga membuat efisiensi pasar, volatilitas harga dan pengembalian imbal hasil saham selalu berubah dari waktu ke waktu yang merupakan sandaran teori penelitian ini guna melihat sejauh mana pengaruh fundamental keuangan perusahaan yang merupakan jendela dan sumber informasi yang paling mendasar atas perusahaan terhadap return saham dipasar ekuitas.

\subsection{Hubungan Faktor Fundamental dan Return Saham}

Analisis fundamental adalah analisis mengenai ekonomi, industri dan perusahaan yang berpotensi dapat mempengaruhi nilai saham perusahaan yang berfokus pada statistik laporan keuangan untuk menentukan harga saham dinilai secara tepat (Sukamulja, 2011). Fundamental keuangan perusahaan, menurut kegunaan, tujuan dan sebagai alat analisa, pada umumnya dapat dikategorikan kedalam lima jenis kelompok (Harmono, 2009), yaitu: 1). Rasio Likuiditas yaitu rasio keuangan yang mengidentifikasi serta mengukur 
untuk mengetahui kemampuan perusahaan membayar kewajiban jangka pendeknya; 2). Rasio Solvabilitas merupakan rasio keuangan yang dapat mengidentifikasi serta mengukur kemampuan perusahaan untuk memenuhi kewajiban jangka pendeknya; 3). Rasio Profitabilitas/Rentabilitas yaitu rasio keuangan yang mengukur kemampuan perusahaan menghasilkan laba dengan penjualan maupun investasi; 4). Rasio Aktifitas merupakan rasio keuangan yang mengukur seberapa efektif dan efisien perusahaan mengelola sumber dana yang tersedia, dan yang terakhir, 5). Rasio Pasar yaitu untuk mengukur dan mengidentifikasi harga pasar saham relatif terhadap nilai bukunya. Dalam penelitian ini, peneliti mengambil masing-masing satu jenis rasio dari kelompok yang ada, yang dapat dijabarkan sebagai berikut:

Debt to Asset Ratio (DER) yang semakin tinggi menunjukan semakin besar porsi hutang perusahaan untuk mendanai operasionalnya, yang memberi petunjuk bahwa semakin besar pula resiko perusahaan tersebut untuk bangkrut (Prihadi, 2011). Dengan demikian semakin tinggi DAR suatu perusahaan, akan berdampak negatif terhadap return saham, yang merupakan akibat dari penurunan harga saham karena investor akan cenderung menghindar untuk berinvestasi pada perusahaan beresiko tinggi. Secara umum DAR dapat dirumuskan sebagai berikut: DAR = Total Debt/Total Asset .

Return on Equity (ROE) perusahaan yang tinggi, dapat memberi petunjuk kepada investor bahwa perusahaan tersebut dikelola dan beroperasi dengan efisien untuk menghasilkan keuntungan bagi pemegang saham. Perusahaan yang memiliki ROE yang tinggi cenderung akan disukai oleh investor, karena perusahaan yang mempunyai ROE yang tinggi akan mampu menghasilkan tingkat laba yang tinggi pula, sehingga akan berpengaruh positif terhadap return saham. ROE secara umum dapat dirumuskan sebagai berikut: $\mathrm{ROE}=$ Net Income After Tax/Total Equity.

Total Asset Turn Over (TATO) yang tinggi dapat memberikan petunjuk bahwa semakin efisien perusahaan tersebut mengelola dan memanfaatkan aktiva yang dimilikinya, yang berarti dapat mendorong menigkatnya penjualan dan pendapatan perusahaan yang tentunya akan berdampak positif terhadap harga saham dan return saham. Nilai TATO yang tinggi akan mengurangi ketidakpastian investor menanamkan modalnya, sehingga dari hasil penjualan yang tinggi tersebut diharapkan akan dihasilkan return yang tinggi pula (Astuti, 2006). TATO dapat dihitung dan dirumuskan sebagai berikut: TATO $=$ Net Sales/Total Asset .

Price Book Value (PBV), Semakin tinggi PBV yang dimiliki oleh perusahaan dapat mencermikan bahwa semakin sukses perusahaan menciptakan nilai bagi pemegang sahamnya yang akan berdampak kepada semakin tinggi tingkatkepercayaan investoruntuk menanamkan modalnya yang direfleksikan oleh pasar terhadap prospek perusahaan dimasa yang akan datang, sehingga akan mendorong permintaan terhadap saham akan meningkat, yang dapat mendorong kenaikan harga saham serta return saham menjadi meningkat pula. Tandelilin (2001), menyatakan bahwa hubungan antara nilai buku per lembar saham dan harga pasar dapat dipakai sebagai pendekatan alternatif untuk menentukan nilai suatu saham, karena secara teoritis, nilai pasar suatu saham haruslah mencerminkan nilai bukunya. Secara umum PBV dapat dirumuskan sebagai berikut: PBV = Harga perlembar saham/Nilai buku perlembar saham.

Return saham merupakan selisih harga jual dengan harga beli atas saham yang ditransaksikan, berupa keuntungan (positif return) maupun kerugian (negative return). Return realisasi merupakan return yang telah terjadi dan dapat dihitung dengan menggunakan data historis (Halim, 2005). Secara umum return saham dapat diukur dan dirumuskan sebagai berikut:

$$
\mathrm{RS}=\left(\mathrm{P}-\mathrm{P}_{\mathrm{t}-1}\right) /\left(\mathrm{P}_{\mathrm{t}-1}\right) \times 100 \%
$$

Keterangan:

$\mathrm{RS}=$ Return Saham

$\mathrm{P}=$ Harga penutupan periode $\mathrm{t}$

$\mathrm{P}_{\mathrm{t}-1}=$ Harga Penutupan periode ke $\mathrm{t}-1$

\subsection{Hubungan Kondisi Ekonomi Makro dan Return Saham}

Dalam melihat kinerja perusahaan, biasanya para investor akan melihat fundamental keuangan perusahaan yang merupakan struktur fondasi pembentuk perusahaan agar dapat beroperasi serta mengembangkan diri pada masa yang akan datang, yang diukur dengan menggunakan berbagai macam rasio serta melihat kondisi makro ekonomi yang ada, sebagai pertimbangan yang paling dasar untuk 
melakukan investasi.

Para investor dalam melakukan proses penilaian investasi haruslah memahami dan mengerti betul akan kondisi ekonomi nasional pada suatu negara sebelum mereka mengambil keputusan untuk melakukan investasi. Kondisi ekonomi yang ada merupakan faktor-faktor yang akan mempengaruhi dan memberikan dampak terhadap pendapatan serta biaya investasi yang akan berpengaruh pula terhadap permintaan dan penawaran produk yang dihasilkan oleh investor (Harianto, 1998). Salah satu faktor yang harus dipertimbangkan oleh Investor adalah tingkat laju inflasi. Inflasi adalah sebagai kecenderungan dari harga-harga untuk menaik secara umum dan terus menerus (Boediono, 1982). Karena tingkat inflasi sangat berpengaruh terhadap tingkat investasi yang dapat berdampak terhadap aktifitas perdagangan dan harga saham dipasar modal sesuai dengan imbal hasil yang diharapkan oleh investor. Penelitian terdahulu yang dilakukan oleh Tarrazi dan Gallato (2012), Sari dan Soytas (2005), Nelson (1976), Jaffe dan Mandelker (1976) serta Fama (1981) menyimpulkan bahwa kenaikan tingkat inflasi berpengaruh signifikan negatif terhadap harga saham.

Pahlevi (2012), dengan penelitian yang berjudul Pengaruh Earning per share, Net profitmargin, Debt to asset ratio serta Return on equity terhadap harga saham pada perusahaan yang termasuk dalam indeks LQ45 yang terdaftar di Bursa Efek Indonesia dari tahun 2005 sampai dengan 2008, dengan menggunakan model regresi linier berganda menemukan bukti empiris secara simultan EPS, NPM, DAR dan ROE berpengaruh signifikan terhadap harga saham, sedangkan secara parsial EPS, NPM dan ROE memiliki hubungan yang negatif dengan harga saham.

Markoni (2009), dengan judul penelitian Pengaruh ROE, PBV dan PER terhadap harga saham pada perusahaan Asuransi yang terdaftar di BEI periode tahun 2002-2006, menggunakan regresi linier berganda, dengan variabel independen ROE, PBV dan PER serta varibel dependen Harga Saham, mendapatkan bukti empiris bahwa secara simultan ROE, PBV dan ROE berpengaruh signifikan terhadap harga saham, secara parsial hanya ROE dan PER yang berpengaruh signifikan, sedangkan PBV berpengaruh positif tidak siginifikan terhadap harga saham.

Ihsan (2009) meneliti pengaruh Current
Ratio (CR), Total Asset Turn Over (TATO), Debt to Equity Ratio (DER) dan Return on Investment (ROI) terhadap harga saham industri apparel di BEJ dari tahun 2001-2005, dengan menggunakan metode regresi, mendapatkan kesimpulan penelitian bahwa secara simultan CR, TATO, DER dan ROI memberi pengaruh terhadap harga saham, sedangkan ROI merupakan variabel yang paling dominan mempengaruhi harga saham.

Aisyah (2009) yang penelitianya berjudul pengaruh variabel-variabel keuangan pada initial return saham di pasar perdana terhadap 48 perusahaan go public di Jakarta Stock Exchange dari tahun 2000 - 2004, dengan menggunakan model regresi terdiri dari variabel ROA, TATO, FL, EPS, CR dan ukuran perusahaan dengan initial return, menghasilkan kesimpulan penelitian, variabel keuangan (ROA, TATO, FL, EPS dan CR) berpengaruh signifikan terhadap initial return saham di pasar perdana. Secara parsial dengan tingkat alfa = 0.05 hanya financial leverage yang berpengaruh signifikan, sedangkan dengan tingkat alfa $=0.10$ hanya $\mathrm{CR}$ yang berengaruh siginifikan.

Widjaja (2009) meneliti pengaruh Total Asset Turn Over (TATO) dan Return on Equity (ROE) terhadap respon pasar untuk perusahaan sektor aneka industri yang terdaftar di Bursa Efek Indonesia (BEI) dari tahun 2001 - 2006 dengan variabel penelitian terdiri dari TATO, ROE dan Harga Saham, dengan menggunakan model regresi, mendapatkan kesimpulan bahwa Total Asset Turn Over (TATO) dan Return on Equity (ROE) berpengaruh positif signifikan terhadap harga saham.

Ganto, Khadafi, Albra dan Syamni (2008), melakukan penelitian terhadap pengaruh kinerja keuangan terhadap return saham pada perusahaan manufaktur yang terdaftar di BEI dengan periode pengamatan dari tahun 20022004, menggunakan regresi linier berganda, dengan judul Pengaruh Kinerja Keuangan Perusahaan Manufaktur terhadap return saham di BEI, menyatakan terdapat hubungan yang positif antara ROE, PER, EPS dan return saham, sedangkan PBV menunjukan hubungan yang negatif dengan return saham.

Poernamawatie (2008), dengan judul penelitian Pengaruh Price Book Value (PBV) dan Price Earning Ratio (PER) terhadap return saham pada perusahaan manufaktur yang terdaftar di Bursa Efek Indonesia dari tahun 2003-2006 dengan menggunakan model regresi 
berganda, mendapatkan bukti empiris bahwa variabel PBV dan PER memberi pengaruh yang positif signifikan terhadap Return Saham.

Sasongko dan Wulandari (2006) melakukan penelitian terhadap pengaruh EVA dan rasio-rasio profitabilitas terhadap harga saham pada perusahaan manufaktur di BEJ dengan periode pengamatan dari tahun 20012002, yang variabel penelitianya terdiri dari EVA, ROA, ROE, ROS, EPS dan BEP terhadap harga saham. Dengan menggunakan metode regresi berganda, atas penelitian tersebut didapat kesimpulan bahwa hanya EPS yang berpengaruh terhadap harga saham, sedangkan ROA, ROE, ROS, BEP dan EVA tidak berpengaruh terhadap return saham.

Sari dan Soytas (2005), melakukan penelitian terhadap hubungan inflasi, return saham dan aktifitas nyata di Turki, dengan mengamati wholesale price index (WPI), industrial production index (IP) dan Istambul stock exchange 100 Index (ISE) dari Januari 1986 - Desember 2000 dengan metode HodrickPrescott Filter (HPF) didapat kesimpulan bahwa tidak terdapat korelasi antara inflasi dengan imbal hasil nyata atas saham, dan terdapat hubungan yang negatif antara inflasi dan imbal hasil saham (stock return).

Nuringsih (2005), dengan judul penelitian Analisa pengaruh kepemilikan manajerial, kebijakan utang dan ukuran perusahaan terhadap kebijakan dividen: Studi 1995-1996, dengan variabel independen Kepemilikan, Debt policy (DAR) dan Ukuran perusahaan dengan menggunakan regresi linier berganda mendapatkan bukti empiris bahwa Managerial ownership berpengaruh signifikan, sedangkan Debt policy (DAR) dan ROA berpengaruh negatif signifikan, sedangkan ukuran perusahaan berpengaruh positif tidak signifikan terhadap dividen policy.

\section{Metode Penelitian}

Populasi pada penelitian ini adalah return saham yang berasal dari harga penutupan (closing price) saham perusahaan terbuka sektor pertambangan dai BEI dengan periode pengamatan dari Januari 2007 sampai dengan Desember 2011, dengan menggunakan data time series sebanyak 5 tahun periode pengamatan. Penelitian ini menggunakan teknik pengambilan sampel non-probabilitas, dengan menggunakan metode penelitian sampel purposive sampling (sampling bertujuan), dimana peneliti memiliki kriteria atau tujuan tertentu terhadap sampel yang diteliti, dimana pengambilan sampel yang dilakukan dengan memilih secara sengaja menyesuaikan dengan tujuan penelitian (Purwanto, 2011). Karena industri sektor pertambangan mempunyai karakteristik tersendiri, yaitu investasi yang membutuhkan modal yang sangat besar (padat modal), dengan tingkat resiko serta tingkat ketidakpastian investasi yang sangat tinggi, salah satu alasan pengambilan sampel secara purposive ini dilakukan, dimana sampel harus memenuhi kriteria sebagai berikut:

1. Return saham perusahaan sektor pertambangan yang terdaftar di BEI periode Januari 2007-2011.

2. Menerbitkan Laporan Keuangan pada periode pengamatan pada tahun 20072011

3. Data tersedia untuk dianalisis.

Pengumpulan data yang digunakan dalam penelitian ini adalah metode non perticipant observation, yaitu mengumpulkan data dengan cara dokumentasi dari berbagai sumber yang diolah, dikumpulkan dan tersedia untuk diakses. Pengambilan data dilakukan di Pojok Bursa Efek Universitas Pancasila, ICMD dan website perusahaan yang dijadikan sampel penelitian, serta buku dan jurnal yang relevan dengan penelitian untuk dijadikan refersensi, dengan menggunakan jenis data kuantitatif, yaitu data yang berbentuk angka-angka atau data kuantitatif yang diangkakan (Sugiyono, 2002), yang berdasarkan sumbernya merupakan data sekunder, yaitu data yang diperoleh secara tidak langsung, berupa data yang sudah jadi, yang telah diolah dan dikumpulkan oleh pihak lain.

Variabel yang digunakan dalam penelitian ini terdiri dari variabel independen dan variabel dependen. Variabel independen atau penjelas terdiri dari DAR, ROE, TATO, PBV dan INFLASI. Sedangkan variabel dependen atau yang dijelaskan adalah return saham perusahaan sektor pertambangan yang terdaftar di BEI periode 2007-2011.

Penelitian ini menggunakan metode kuantitatif dengan alat analisis regresi berganda. Analisis regresi berganda digunakan untuk menguji pengaruh DAR, ROE, TATO, PBV dan INFLASI terhadap Return Saham. Untuk mengetahui seberapa besar variabel independen 
mempengaruhi variabel dependen dihitung dengan menggunakan persamaan garis regresi berganda sebagai berikut:

$\mathrm{Y}=\mathrm{a}+\mathrm{b} 1 \mathrm{x} 1+\mathrm{b} 2 \times 2+\mathrm{b} 3 \times 3+\mathrm{b} 4 \times 4+\mathrm{b} 5 \times 5+\mathrm{e}$

Keterangan:

$\mathrm{Y}=$ Return Saham perusahaan sektor pertambangan

$\mathrm{a}=$ Konstanta

$\mathrm{b} 1-\mathrm{b} 5=$ Koefisien regresi

$\mathrm{X} 1=$ Debt to Asset Ratio (DAR)

$\mathrm{X} 2=$ Return on Equity (ROE)

$\mathrm{X} 3=$ Total Asset Turn Over (TATO)

$\mathrm{X} 4=$ Price Book Value $(\mathrm{PBV})$

$\mathrm{X} 5=$ Tingkat Inflasi (INFLASI)

$\mathrm{E}=$ Standar Error

Nilai koefisien regresi sangat berarti sebagai dasar analisis. Koefisien b akan bernilai positif $(+)$ apabila menunjukan hubungan yang searah antara variabel independen dengan variabel dependen, yang berarti setiap kenaikan variabel independen akan mengakibatkan kenaikan variabel dependen, begitu pula sebaliknya. Sedangkan nilai b bertanda negatif (-) menunjukan hubungan yang berlawanan, artinya setiap kenaikan variabel independen akan mengakibatkan penurunan variabel dependen, demikian pula sebaliknya.

Uji asumsi klasik dilakukan dengan melakukan deteksi gejala penyakit asumsi klasik yang meliputi multikolinieritas, autokorelasi, hetereskedastisitas, dan berdistribusi dengan normal. Untuk mengetahui ada tidaknya gejalagejala tersebut maka terlebih dahulu dilakukan uji asumsi klasik. Untuk mendeteksi ada atau tidaknya multikolinieritas dapat dilihat dari nilai Tolerance Value atau Variance Inlflation Factor (VIF), batas nilai VIF adalah 10, apabila nilai VIF lebih besar dari 10 maka terjadimultikolinearitas, akan tetapi apabila nilai VIF dibawah 10 maka tidak terdapat multikolinieritas (Wijaya, 2011). Sedangkan untuk mendeteksi ada atau tidaknya autokorelasi terhadap suatu model, maka nilai DW dapat dibandingkan dengan nilai DW tabel (Priyatno, 2012). Apabila DW $<\mathrm{dL}$ atau $\mathrm{DW}>-\mathrm{dL}$ berarti terdapat autokorelasi, jika DW terletak antara dU dan 4-dU berarti tidak ada autokorelasi, sedangkan bila DW terletak antara dL dan dU atau diantara 4-dU dan 4-dL maka tidak dapat ditarik kesimpulan. Heteroskedastisitas dapat dideteksi dengan melihat grafik plot antara nilai prediksi variabel terikat (ZPRED) dengan residualnya (SRESID) dengan melihat ada atau tidaknya pola tertentu seperti titik-titik yang ada membentuk pola tertentu yang teratur, bergelombang, melebar kemudian menyempit pada grafik scaterplot antara ZPRED dan SRESID pada sumbu Y prediksi dan sumbu $\mathrm{X}$ residual mengindikasikan terdapat heteroskedastisitas, sedangkan apabila tidak terdapat pola tertentu yang jelas, titiktitik menyebar diatas dan dibawah angka 0 pada sumbu Y, diindikasikan tidak terjadi heteroskedastisitas (Wijaya, 2011).

Uji normalitas dapat dilakukan dengan melihat normal probability plot dengan melihat penyebaran data (titik) pada sumbu diagonal atau grafik. Apabila data (titik) menyebar disekitas garis diagonal dan mengikuti arah garis diagonal maka model regresi memenuhi asumsi normalitas, sedangkan apabila data (titik) menyebar jauh dari garis diagonal atau tidak mengikuti arah garis diagonal maka model regresi ini tidak memenuhi asumsi normalitas (Ghozali, 2011).

Pengujian hipotesis dilakukan dengan analisis linier berganda (multiple regression) yang dimaksudkan untuk mengetahui pengaruh DAR, ROE, TATO, PBV dan INFLASI terhadap return saham perusahaan sektor pertambangan yang terdaftar di BEI secara simultan (bersama - sama) maupun secara parsial (individu).

Koefisien Determinasi $\left(\mathrm{R}^{2}\right)$ digunakan untuk mengukur seberapa besar kemampuan model menerangkan variasi variabel dependen. Nilai koefisien determinasi adalah antara 0 dan 1. Nilai $\mathrm{R}^{2}$ yang kecil berarti kemampuan variabel independen dalam menjelaskan variasi variabel amat terbatas, sedangkan nilai $\mathrm{R}^{2} \mathrm{yang}$ mendekati 1, menyatakan bahwa variabel independen memberikan hampir semua informasi yang dibutuhkan untuk memprediksi variasi varibel dependen (Wijaya, 2011).

Sedangkan pengujian koefisien regresi secara simultan (Uji-F) dilakukan untuk mengetahui pengaruh semua variabel independen yang terdapat dalam model secara bersama-sama (simultan) terhadap variabel dependen. Dengan cara menentukan tingkat signifikansi sebesar 5\% $(\alpha=0,05)$, kemudian mebandingkan F-hitung dengan F-tabel, apabila F-hitung < F-tabel berarti variabel independen secara simultan tidak berpengaruh terhadap variabel dependen, sedangkan apabila F-hitung $>$ F-tabel berarti variabel independen secara simultan berpengaruh terhadap variabel dependen (Gujarati, 1999). 
Pengujian koefisien regresi secara parsial (Uji-t) dilakukan untuk mengetahui signifikansi secara parsial peran variabel independen terhadap variabel dependen dengan mengasumsikan variabel independen dianggap konstan atau sama dengan nol. Dengan tingkat signifikansi 95\%, nilai t-hitung dari masing -

Tabel 2

Descriptive Statistics

\begin{tabular}{lrrrrr}
\hline & N & \multicolumn{1}{c}{ Minimum } & \multicolumn{1}{c}{ Maximum } & \multicolumn{1}{c}{ Mean } & Std. Deviation \\
\hline PS & 55 & -16.99 & 23.92 & 2.4544 & 7.79325 \\
DAR & 55 & 14.00 & 85.00 & 46.2727 & 20.80817 \\
ROE & 55 & -29.33 & 84.60 & 22.7293 & 21.29049 \\
TATO & 55 & .00 & 217.57 & 78.1856 & 56.69344 \\
PBV & 55 & 33.00 & 1397.00 & 339.7636 & 317.51973 \\
INFLASI & 55 & 4.90 & 10.31 & 6.5240 & 1.98508 \\
Valid N (listwise) & 55 & & & & \\
\hline
\end{tabular}

masing koefisien regresi kemudian dibandingkan dengan nilai t-tabel. Jika nilai t-hitung $>$ dari nilai t-tabel atau prob-sig $<\alpha=$ $5 \%$ berarti masing-masing variabel independen berpengaruh terhadap variabel dependen.

\section{Hasil Penelitian Dan Pembahasan}

Sampel penelitian ini adalah perusahaan sektor pertambangan yang go-public dan tercatat di BEI dari tahun 2007 - 2011, sebanyak 11 perusahaan terpilih dan memenuhi syarat dari 32 perusahaan yang terdaftar di BEI. uji statistik deskriptif untuk mengetahui karakteristik sampel yang meliputi jumlah sampel, rata-rata sampel, tingkat penyimpangan penyebaran data (standard deviation), nilai maksimum dan nilai minimum data yang ada, seperti pada tabel 2. 
Tabel 3

Nilai Toleransi dan VIF Variabel Bebas

\begin{tabular}{lll}
\hline \multicolumn{1}{c}{ Model } & \multicolumn{2}{c}{ Collinearity Statistics } \\
& Tollerance & VIF \\
\hline 1. (Constant) & & \\
DAR & .929 & 1.077 \\
ROE & .615 & 1.626 \\
TATO & .745 & 1.342 \\
PBV & .715 & 1.398 \\
INFLASI & .866 & 1.154 \\
\hline \multicolumn{2}{c}{ Sebelum } & \multicolumn{2}{c}{ melakukan }
\end{tabular}

menginterpretasikan hasil analisis regresi, perlu dilakukan uji asumsi klasik terhadap model regresi agar variabel independen sebagai estimator terhadap variabel dependen tidak bias, sehingga tujuan dan bukti empiris terhadap penelitian dapat dicapai dengan baik. Untuk menguji apakah model regresi yang ada terdapat korelasi antar variabel bebas (variabel independen) yang menyebabkan multikolinieritas maka dapat dilihat dari nilai tolerance yang lebih kecil dari 0,1 atau nilai VIF yang lebih besar dari 10 (Hair et all, 1992) dalam Priyanto (2012). Dari Tabel 3 diatas dapat dilihat tidak terdapat variabel bebas yang mempunyai nilai toleransi yang kurang dari $10 \%$ begitu pula dengan nilai VIF-nya tidak ada variabel bebas yang mempunyai nilai lebih dari 10, sehingga dapat disimpulkan model regresi yang digunakan tidak terdapat gejala multikolinieritas.

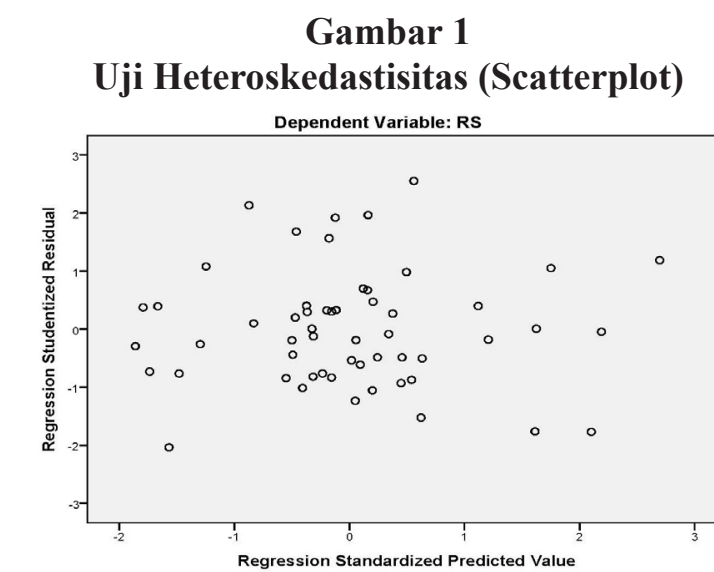

Untuk menguji ada atau tidak heteroskedastisitas dalam model, salah satu cara untuk melihatnya adalah dengan melihat grafik plot antara nilai prediksi variabel terikat (ZPRED) terhadap residualnya (SRESID), jika titik-titik memiliki pola tertentu yang teratur seperti gelombang, melebar, kemudian menyempit, maka mengindikasikan adanya heteroskedastisitas, apabila titik-titik menyebar secara acak diatas dan dibawah angka 0 pada sumbu Y, mengindikasikan tidak terjadi heteroskedastisitas (Wijaya, 2011). Terlihat dari Gambar 1 seperti diatas terlihat sebaran titik-titik yang acak baik diatas maupun dibawah angka 0 pada sumbu Y sehingga dapat disimpulkan bahwa tidak terjadi heteroskedastisitas dalam model regresi.

Uji normalitas dilakukan guna melihat apakah dalam model regresi variabel bebas

Tabel 4

Uji Autokorelasi (Model Summary)

\begin{tabular}{cccccc}
\hline Model & $\mathbf{R}$ & R Square & $\begin{array}{c}\text { Adjusted } \\
\text { R Square }\end{array}$ & $\begin{array}{c}\text { Std. Error } \\
\text { of the Estimate }\end{array}$ & Durbin - Watson \\
\hline 1 & $.748^{\mathrm{a}}$ & .560 & .515 & 5.42696 & 2.214 \\
\hline
\end{tabular}

Untuk mendeteksi ada atau tidaknya autokorelasi, maka nilai DW dapat dibandingkan dengan DW tabel, dengan kriteria sebagai berikut (Priyanto, 2012): 1). Jika DW $<\mathrm{dL}$ atau DW > -dL berarti terdapat korelasi; 2). Jika DW terletak antara dU dan 4-dU, tidak ada korelasi; 3). Jika dW terletak antara dL dan $\mathrm{dU}$ atau diantara 4-dU dan 4-dL tidak dapat ditarik kesimpulan. Berdasarkan Tabel 4. diatas didapat nilai DW sebesar 2.214, sehingga dapat disimpulkan terhadap model yang ada tidak terdapat korelasi, karena nilai yang diperoleh terletak antara dU (1.7681) dan 4-dU (2.2319). dan varibel terikat berdistribusi dengan normal atau tidak. Model regresi yang baik adalah model regresi yang berdistribusi secara normal (Wijaya, 2011). Berdasarkan Gambar 4 diatas, atas hasil oleh data yang ada grafik histogram terlihat menunjukan pola berdistribusi normal. 
Gambar 2

Normal Probability Plot

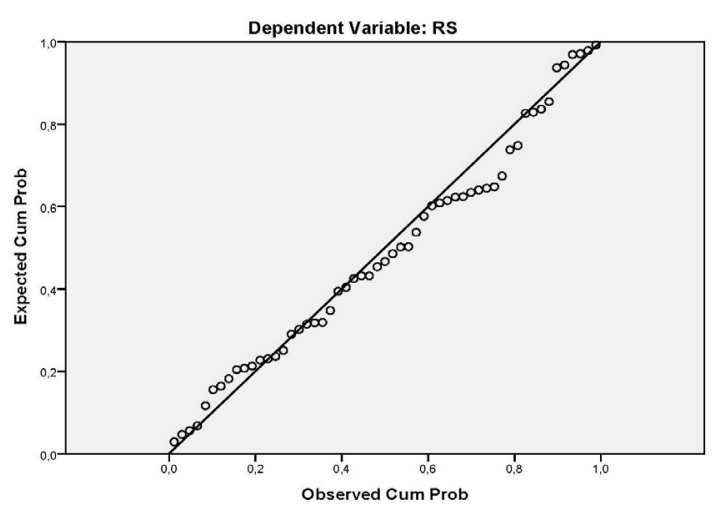

Sedangkan pada Gambar 2. grafik normal probabiliti plot menunjukan pola penyebaran titik-titik disekitar garis diagonal, dan mengikuti arah garis diagonal, yang mengindikasikan model regresi memenuhi asumsi normalitas.

Tabel 5.

Pengujian Goodness of Fit

\begin{tabular}{ccccc}
\hline Model & $\mathbf{R}$ & $\begin{array}{c}\mathbf{R} \\
\text { Square }\end{array}$ & $\begin{array}{c}\text { Adjusted } \\
\text { R Square }\end{array}$ & $\begin{array}{c}\text { Std. Error } \\
\text { of the Estimate }\end{array}$ \\
\hline 1 & $.748^{\mathrm{a}}$ & .560 & .515 & 5.42696 \\
\hline
\end{tabular}

Nilai adjusted R square pada Tabel 5 . diatas adalah sebesar 0,515 yang menunjukan bahwa 51,50\% variabel RS dapat dijelaskan oleh variabel independen (DAR, ROE, TATO, PBV dan Inflasi), sedangkan sisanya sebesar 48, $50 \%$ dipengaruhi oleh variabel lain yang tidak dapat dijelaskan oleh model dalam penelitian ini.

Tabel 6.

Hasil Perhitungan Uji F

ANOVA $^{b}$

\begin{tabular}{lcrrrr}
\hline Model & $\begin{array}{c}\text { Sum of } \\
\text { Squares }\end{array}$ & df & $\begin{array}{c}\text { Mean } \\
\text { Square }\end{array}$ & F & Sig \\
\hline 1 Regresion & 1836.521 & 5 & 367.304 & 12.471 & $.000^{a}$ \\
Residual & 1443.157 & 49 & 29.452 & & \\
Total & 3279.679 & 54 & & & \\
\hline
\end{tabular}

a. Predictors: (Constant), Inflasi, DAR, PBV, TATO, ROE

b. Dependent Variabel: Return Saham

Dari Tabel 6 diatas, dapat dilihat bahwa nilai $\mathrm{F}_{\text {hitung }}$ adalah sebesar 12.471 dengan tingkat signifikansi 0.000 , sedangkan $\mathrm{F}_{\text {tabel }}$ pada tingkat kepercayaan $95 \%(\alpha=0,05)$ adalah 2,40 dengan demikian nilai $\mathrm{F}_{\text {hitung }}>\mathrm{F}_{\text {tabel }}(12.47>2,40)$ dengan nilai signifikansi sebesar 0,000 yang berarti kurang dari 5\%, maka Hipotesis FaktorFaktor Fundamental Keuangan Perusahaan yang diwakili oleh DAR, ROE, TATO, PBV dan INFLASI secara simultan berpengaruh signifikan terhadap return saham.

\section{Tabel 7}

Hasil Perhitungan Uji-t

\begin{tabular}{|c|c|c|c|c|c|}
\hline \multirow[t]{2}{*}{ Model } & \multicolumn{2}{|c|}{$\begin{array}{l}\text { Unstandardized } \\
\text { Coefficients }\end{array}$} & \multicolumn{2}{|c|}{$\begin{array}{c}\text { Standardized } \\
\text { Coefficiens }\end{array}$} & \multirow[b]{2}{*}{ Sig } \\
\hline & $\overline{\mathbf{B}}$ & Std. Error & Beta & $\mathbf{t}$ & \\
\hline (Con & 8.662 & 3.281 & & 2.640 & .01 \\
\hline DAR & -.016 & 0.37 & -.044 & -.444 & .659 \\
\hline $\mathrm{ROE}$ & .001 & .044 & .003 & .027 & .979 \\
\hline TATO & .018 & .015 & .128 & 1.169 & .248 \\
\hline PBV & .013 & .003 & .533 & 4.757 & .000 \\
\hline INF & -1.733 & .400 & -.441 & -4.334 & .000 \\
\hline
\end{tabular}

Dari tabel koefisien atas hasil uji-t seperti pada Tabel 7 diatas, dapat disusun persamaan regresi linier bergada sebagai berikut:

$$
\begin{aligned}
\mathrm{RS}= & 8.662-0.016 \mathrm{DAR}+0.001 \mathrm{ROE}+0.018 \mathrm{TATO} \\
& +0.013 \mathrm{PBV}-1.7331 \mathrm{INF}+\mathrm{e}
\end{aligned}
$$

Berdasarkan hasil uji-t, didapat angka konstanta sebesar 8.662 yang menyatakan jika variabel indenden (DAR, ROE, TATO, PBV) dan Inflasi dianggap konstan atau sama dengan nol, maka nilai return saham adalah sebesar 8.662. Arah pengaruh variabel independen terhadap variabel dependen dapat dilakukan dengan melihat standardize beta coefficients (Ghozali, 2011). Berdasarkan hasil uji statistik hanya variabel PBV yang berpengaruh paling signifikan positif dengan standardize beta coefficients sebesar 0.553 , sedangkan yang paling berpengaruh signifikan negatif adalah variabel Inflasi dengan nilai -.441. Hasil pengujian hipotesis yang dilakukan secara parsial atas variabel independen terhadap return saham adalah sebagai berikut:

1. DAR (X1) dengan nilai koefisien regresi sebesar -.016, nilai t-hitung -.444 serta nilai signifikansi 0.659 lebih besar dari $\alpha(0,05)$ dengan demikian tidak terdapat pengaruh signifikan antara DAR dengan RS. Angka koefisien regresi tersebut menunjukan apabila variabel DAR meningkat 1 satuan, maka akan menurunkan RS sebesar 0.016 dengan arah yang berlawanan, dengan asumsi variabel lain tetap atau sama dengan nol.

2. ROE (X2) dengan koefisien regresi sebesar .001, nilai t-hitung .027 dengan nilai signifikansi 0.979 lebih besar dari $\alpha(0,05)$ dapat diartikan bahwa tidak 
terdapat pengaruh signifikan antara ROE (X2) dengan RS, apabila variabel ROE meningkat 1 satuan maka akan menaikan RS sebesar 0.001 dengan arah yang sama, dengan asumsi variabel lain tetap atau sama dengan nol.

3. TATO (X3) dengan koefisien regresi sebesar .018, nilai t-hitung 1.169 dengan nilai signifikansi 0.248 lebih besar dari $\alpha(0,05)$ dapat diartikan bahwa tidak terdapat pengaruh signifikan antara TATO (X3) dengan RS, apabila variabel TATO meningkat 1 satuan maka akan menaikan RS sebesar 0.018 dengan arah yang sama, dengan asumsi variabel lain tetap atau sama dengan nol.

4. PBV (X4) dengan koefisien regresi sebesar .013 , nilai t-hitung 4.757 dengan nilai signifikansi 0.000 lebih kecil dari $\alpha(0,05)$ dapat diartikan bahwa terdapat pengaruh signifikan antara PBV (X4) dengan RS, apabila variabel PBV meningkat 1 satuan maka akan menaikan RS sebesar 0.013 dengan arah yang sama, dengan asumsi variabel lain tetap atau sama dengan nol.

5. INFLASI (X5) dengan koefisien regresi sebesar -1.733, nilai t-hitung -4.334 dengan nilai signifikansi 0.000 lebih kecil dari $\alpha(0,05)$ dapat diartikan bahwa terdapat pengaruh signifikan antara INFLASI (X5) dengan RS, apabila variabel INF meningkat 1 satuan maka akan menurunkan RS sebesar 1.733 dengan arah yang berlawanan, dengan asumsi variabel lain tetap atau sama dengan nol.

Berdasarkan hasil uji statistik, dapat dibuktikan secara empiris bahwa faktorfaktor fundamental keuangan perusahaan sektor pertambangan periode 2007-2011 yang diwakili oleh DAR, ROE, TATO dan PBV serta Makro Ekonomi yang diwakili oleh inflasi secara bersama-sama (simultan) berpengaruh signifikan terhadap return saham sektor pertambangan yang go-public di BEI periode 2007-2011. Sedangkan secara parsial dapat dijelaskan sebagai berikut:

Debt to Asset Ratio (DAR) berpengaruh tidak signifikan negatif terhadap return saham, hal ini sejalan dengan penelitian yang dilakukan oleh Sugeng Raharjo (2011), sesuai dengan karakteristik dari industri pertambangan tersebut yang hampir sebagian besar aktiva yang dimiliki berasal dari hutang. Industri pertambangan adalah industri padat modal yang memerlukan modal investasi yang besar, dengan mengutamakan pertumbuhan jangka panjang, sehingga investor tidak terlalu terpengaruh dengan DAR industri ini, sepanjang masih bersifat wajar.

Return on Equity (ROE) tidak berpengaruh terhadap terhadap return saham, karena investor menyadari bahwa ekuitas serta pembiayaan operasional perusahaan tersebut yang sebagai besar berasal dari hutang, sehingga investor tidak terlalu menghiraukan seberapa besar pengembalian ekuitas yang dihasilkan perusahaan untuk berinvestasi pada saham di sektor ini, karena sifatnya yang mengutamakan pertumbuhan jangka panjang. Hasil penelitian ini sejalan dengan temuan penelitian yang dilakukan oleh Pahlevi (2012), Mukhtarudin dan Romalo (2007) serta Sasongko dan Wulandari (2006).

Total Asset Turn Over (TATO) tidak berpengaruh terhadap return saham, hal ini dikarenakan asset yang terbesar yang dimiliki oleh industri pertambangan berupa bahan galian yang tersimpan didalam bumi yang kepemilikanya sesuai dengan undang-undang masih dikuasai sepenuhnya oleh negara, sedangkan perusahaan hanya mempunyai hak (right) untuk mengusahakan penambangan, hal inilah yang menyebabkan investor tidak terlalu mempertimbangkan TATO, sehingga return saham disektor industri ini tidak terlalu dipengaruhi oleh tingkat perputaran asset yang ada, sejalan dengan hasil penelitian yang dilakukan oleh Ihsan (2009) serta Ganto, Khadafi, Albra dan Syamsi (2008).

Price Book Vaule (PBV) merupakan faktor fundamental keuangan perusahaan yang paling dominan berpengaruh positif terhadap return saham, hasil penelitian ini sejalan dengan penelitian yang dilakukan oleh Fidiana (2009) serta Poernamawatie (2008) dikarenakan para investor lebih melihat dan menghargai nilai dan pertumbuhan perusahaan yang tercermin dari nilai bukunya dibandingkan dengan rasio fundamental lainya, karena industri ini membutuhkan investasi yang besar, padat modal dan pertumbuhan jangka panjang. Hasil penelitian ini dapat membuktikan bahwa tingkat perubahan PBV memiliki dampak yang lebih besar dan positif terhadap return saham sektor pertambangan yang go-public di BEI dibandingkan dengan faktor fundamental lainnya, yang patut dicermati dan diperhatikan 
oleh investor. Hal ini membuktikan bahwa jaminan atas nilai perusahaan dan pertumbuhan berkelanjutan jangka panjang dari ekuitas terhadap nilai bukunya memiliki tingkat kemampuan yang lebih besar dalam memberikan tingkat pengembalian investasi yang di inginkan oleh investor.

Inflasi merupakan variabel yang paling signifikan negatif berpengaruh terhadap return saham, hal ini sejalan dengan penelitian yang dilakukan oleh Tarazi dan Gallato (2012), Geetha, Mohidin, Chandran dan Victori (2011) serta Sari dan Soytas (2005) yang menyatakan bahwa terdapat hubungan yang negatif antara inflasi dan return saham.

Dengan demikian informasi fundamental yang berasal dari laporan keuangan, yang dapat dianalisis merupakan suatu hal yang patut diperhatikan dan dipertimbangkan oleh investor, karena dalam pemilihan investasi informasi dipasar modal akan selalu dipengaruhi oleh informasi fundamental dan informasi teknikal (Chung, 1997) serta pengaruh makro ekonomi merupakan suatu hal yang tidak terpisahkan sebagai alat analisis yang harus dicermati oleh investor karena jika kondisi atau indikator makro ekonomi mendatang diperkirakan jelek, maka kemungkinan besar refleksi indeks harga saham menurun, demikian pula sebaliknya (Ang, 1997).

\section{Simpulan, Keterbatasan, dan Implikasi Hasil Penelitian}

Berdasarkan hasil pembahasan atas penelitian Analisis Faktor-Faktor Fundamental Keuangan Perusahaan dan Makro Ekonomi sektor industri pertambangan periode 20072011, maka dapat ditarik kesimpulan sebagai berikut:

1. Secara simultan faktor-faktor fundamental keuangan perusahaan DAR, ROE, TATO, PBV serta INFLASI berpengaruh signifikan terhadap return saham

2. Sedangkan secara parsial hanya PBV yang berpengaruh signifikan positif dan INFLASI berpengaruh signifikan negatif, sedangkan varibel DAR, ROE serta TATO tidak berpengaruh terhadap return saham.

Penelitian ini memiliki keterbatasan, antara lain populasi yang dipergunakan terbatas pada perusahaan sektor pertambangan yang tercatat di BEI, periode data penelitian yang relatif singkat yaitu dari tahun 2007-2011, serta keterbatasan untuk mendapatkan data laporan keuangan yang up-to-date terhadap perusahaan yang dijadikan sampel penelitian, baik di website masing-masing perusahan maupun di website BEI, sehingga sampel penelitian yang didapat menjadi lebih sedikit dari seharusnya yang dapat dijadikan sampel penelitian. Untuk penelitian yang akan datang disarankan agar memperluas cakupan fundamental keuangan perusahaan, sektor industri yang ada tidak terbatas hanya pada sektor pertambangan saja dengan menambah periode penelitian yang lebih panjang sehingga hasil yang didapatkan akan menjadi lebih valid dan mempunyai kekuatan generalisasi yang lebih kuat. Begitupula dengan variabel-variabel makro ekonomi yang perlu ditambah menjadi lebih banyak, karena faktor makro ekonomi ini menjadi influence yang mendapatkan perhatian serius dari Investor untuk membuat pertimbangan guna mengambil keputusan investasi, karena merupakan salah satu determinan utama yang disyaratkan untuk berinvestasi pada saham suatu perusahaan.

\section{Daftar Pustaka}

Ang, Robert, (1997), Buku pintar: Pasar modal Indonesia, first edition, Mediasoft Indonesia.

Aisyah, Isye Siti (2009), Pengaruh variabelvariabel keuangan pada initial return saham di pasar perdana, terhadap 48 perusahaan yang melakukan IPO di BEJ dari tahun 2000 - 2004, Trikonomika, Vol.8 No.1, Juni 2009.

Boediono (1982), Teori Pertumbuhan Ekonomi, Seri Sinopsis pengantar ilmu ekonomi Nomor 4, BPFE, Yogyakarta.

Chung et al, (1997), "The Effect Of Macroeconomic Variabels On Stock Market returns In Developing Markets", Multinational Bussibess Review/Fall, pp 63-70

Fama, E.F (1981) Stocks return, real actifity, inflation and money, The American Economic Review 71 (4): 45 - 565

Fidiana (2009), Nilai-nilai fundamental dan pengaruhnya terhadap beta saham syariah pada Jakarta Islamic Indeks, Ekuitas Vol.13 No.1, Maret 2009.

Ganto,Jullimursyida., Khadafi, Muammar., Albra, Wahyudin., Syamni, Gazali. (2008), Pengaruh Kinerja Keuangan Perusahaan 
Manufaktur Terhaap Return Saham di Bursa Efek Indonesia, Media Riset Akuntansi, Auditing dan Informasi, Vol. 8 No.1, April 2008

Geetha, Caroline., Mohidin, Rosle., Chandran, Vivin Vincent., and Chong, Victoria (2011), The relationship between inflation and stock market: Evidence from Malaysia, United States and China, International Journal of Economics and Management Sciences Vol.1 No.2, 2012, pp $01-06$.

Ghozali, Imam (2011), Aplikasi analisis multivariate dengan program SPSS, BP Undip Semarang.

Gujarati, Damodar (1999), Ekonometrika Dasar, Erlangga, Jakarta

Halim, A (2005), Analisis Investasi, Jakarta, Salemba Empat.

Hanafi, Mamduh M, (2005), Analisis Laporan Keuangan, Unit Penerbit dan Percetakan AMP YKPN, Yogjakarta.

Harahap, Zulkifli dan Pasaribu, Agusni (2007), Pengaruh faktor fundamental dan resiko sistematik terhadap harga saham pada perusahaan manufaktur yang terdapat di BEJ, MEPA Ekonomi, Januari 2007, Voulme 2, Nomor 1.

Harianto, Farid dan Sudomo, Siswanto (1998), Perangkat dan teknik analisis investasi di pasar modal Indonesia, BEJ, Jakarta.

Harmono, (2009), Manajemen Keuangan berbasis balance scorecard pendekatan teori, kasus dan riset bisnis, Bumi Aksara, Jakarta.

Ihsan, Mohamad (2009), Pengaruh Current Ratio, Total Asset Turn Over, Debt to Equity Ratio dan ROI terhadap harga saham industri apparel di Bursa Efek Jakarta, Jurnal Percikan, Vol.96, Edisi Januari 2009.

Jaffe, J \& Mandelkar, G. (1976), The Fisher effect for risky assets: An emprical investigations, Journal of Finance, 31: 447 - 456.

Markoni (2009), Pengaruh return on equity, price to book value, dan price earning ratio terhadap harga saham pada perusahaan asuransi BEI, Jurnal Manajemen dan Kewirausahaan, Vol. 2. No.2, Juli 2009.

Martani, Dwi, Mulyono dan Khairurizka, Rahfiani (2009), The effect of financial ratios, firm size, and cash flow from operating actifities in the interim report to the stock return, Chinese Business Review, ISSN 1537-1506, June 2009, Volume 8, No.6 (Serial No.72), USA.
Nelson, C.R. (1976), Inflation and rates of Return on Common Stocks, Journal of Finance, 40 (2): 471 - 245.

Nuringsih, Kartika (2005), Analisis Pengaruh Kepemilikan Manajerial, Kebijakan Utang, ROA dan Ukuran Perusahaan terhadap Kebijakan Dividen: Studi 1995-1996, Jurnal Akuntansi dan Keuangan Indonesia, Juli - Desember 2005, Vol.2, No.2.

Pahlevi, Reza, (2012), Pengaruh EPS, NPM, DAR dan ROE terhaap harga saham pada perusahaan yang masuk dalam indeks LQ45 yang terdaftar di BEI, ejournal ekonomi Univeristas Gunadarma, September 2012.

Poernamawatie, Fahmi (2008), Pengaruh Price Book Value (PBV) dan Price Earning Ratio (PER) terhadap Return Saham pada perusahaan Manufaktur yang terdaftar di Bursa Efek Indonesia, Jurnal Manajemen Gajayana, Vol.5, No.2, Nopember 2008.

Priyatno, Duwi (2012), Belajar cepat olah data statistik dengan SPSS, Andi Offset, Yogyakarta.

Prihadi, Toto (2011), Analisis Laporan Keuangan, Teori dan Aplikasi, cetakan kedua, PPM, Jakarta.

Purwanto (2011), Statistika untuk penelitian, Cetakan Pertama, Pustaka Pelajar, Jogjakarta.

Raharjo, Sugeng (2011), Analisis pengaruh variabel ekonomi makro dan rasio keuangan terhadap harga saham pada perusahaan manufaktur di BEI, Jurnal Ekonomi dan Bisnis Vol.19 No. 15, Maret 2011.

Sasongko, Noer dan Wulandari, Nila (2006), PengaruhEVAdanRasio-RasioProfitabilitas terhadap harga saham, Empirika,Vol.19 No.1, Juni 2006.

Sari, Ramazan and Soytas, Ugur (2005), Inflation, stock returns and real actifity in Turkey, The empirical economic letter 4 (3) -2005 .

Sugiyono. 2002,Metode Penelitian Bisnis, Buku 1. Bandung: CV Alfabeta.

Sukamulja, Sukmawati (2011), Analisis Fundamental, Teknikal dan Program Metastock,http://www.akuntan.fe.ugm. ac.id/file/File/5-Analisis Fundamental Teknikal.doc, diakses tanggal 25 Maret 2011.

Tandelilin, Eduardus (2001), Analisis investasi manajemen portofolio, Cetakan pertama, BPFE Yogyakarta

Tarazi, Ramzi E.N and Gallato, Cristina 
(2012), Determinants of Expected Stock Returns: Evidence Malaysian and Thai Markets, available at: http:/ssrn.com/ abstract $=2167679$

Weston, F.J dan Copeland, E.T. (1992), Manajemen Keuangan, Terjemahan oleh Jaka Wasana dan Kibrandoko (1995), Bina Aksara, Jakarta.

Widjaja, Indra (2009), Pengaruh Current Ratio dan Ukuran Perusahaan terhadap return saham Perusahaan Industri Dasar dan Kimia, Jurnal Organisasi dan Manajemen, Tahun II/4, Oktober 2009, pp 27 - 37.

Wijaya, Tony (2011), Cepat menguasai SPSS 19, untuk olah dan interpretasi data penelitian dan skripsi, Cahaya Atma, Jogjakarta. 